\title{
Wetlands in flux: looking for the drivers in a central European case
}

\author{
Tomasz Berezowski - Martin Wassen $(\mathbb{D} \cdot$ Jan Szatyłowicz $\mathbb{D} \cdot$ Jarosław Chormański • \\ Stefan Ignar • Okke Batelaan $(\mathbb{D} \cdot$ Tomasz Okruszko
}

Received: 1 September 2017/ Accepted: 8 June 2018/Published online: 13 June 2018

(C) The Author(s) 2018

\begin{abstract}
Planet Earth is undergoing significant changes which are driven by natural and anthropogenic factors. However, it is difficult to identify the drivers and their effect on the environment and ecosystems because there are many interdependencies. In this study we present a multi-parameter approach to assess the effect of changes in humaninduced and natural drivers on a wetland ecosystem. The study area is one of the most prominent European wetlands: the Biebrza Basin, located in north-eastern
\end{abstract}

Electronic supplementary material The online version of this article (https://doi.org/10.1007/s11273-018-9613-z) contains supplementary material, which is available to authorized users.

Present Address:

T. Berezowski $(\square)$

Department of Geoinformatics, Faculty of Electronics, Telecommunication and Informatics, Gdansk University of Technology, Gabriela Narutowicza 11/12, 80-233 Gdansk, Poland

e-mail: tomberez@eti.pg.edu.pl

T. Berezowski · J. Chormański · S. Ignar · T. Okruszko Department of Hydraulic Engineering, Warsaw University of Life Sciences, Nowoursynowska 166, 02-787 Warsaw, Poland

e-mail: j.chormanski@levis.sggw.pl

S. Ignar

e-mail: s.ignar@levis.sggw.pl

T. Okruszko

e-mail: t.okruszko@sggw.pl
Poland. We analysed long-term (ca. 1960-2000) changes in meteorology, hydrology, soil and vegetation, and also conservation history. This approach enabled us to identify interactions between environmental change and management. We found significant trends (1960-2012) indicating climate change: increases in temperature, evapotranspiration and earlier start of spring floods. We identified (1970-2000) a shift towards drier vegetation types after drainage. However, we also found that restoration measures that were implemented have mitigated climate change effects and have led to increases in soil moisture and wetter vegetation types. We conclude that, if carried out sufficiently frequently, the management measures

\section{Wassen}

Copernicus Institute of Sustainable Development, Utrecht University, Princetonlaan 8a, 3584 CB Utrecht, The

Netherlands

e-mail: M.J.Wassen@uu.nl

J. Szatyłowicz

Department of Environmental Improvement, Warsaw

University of Life Sciences, Nowoursynowska 166,

02-787 Warsaw, Poland

e-mail: jan_szatylowicz@sggw.pl

O. Batelaan

National Centre for Groundwater Research and Training, College of Science and Engineering, Flinders University, GPO Box 2100, Adelaide, SA 5001, Australia

e-mail: Okke.batelaan@flinders.edu.au 
implemented in the Biebrza Basin, which are a combination of different restoration measures (blocking drainage, not clearing aquatic vegetation, bush removal, mowing), can to some extent mitigate the effects of climate change.

Keywords Management - Restoration - Climate change $\cdot$ Hydrogenic soils $\cdot$ Hydrology $\cdot$ Vegetation

\section{Introduction}

We are currently in the Anthropocene (Crutzen and Stoermer 2000), an era that has arisen since the Industrial Revolution, in which human actions have become the main driver of global environmental change. Human interferences are large scale and manifold and include extraction of resources from the geosphere, interference in the cycles of water, carbon and nutrients in all spheres, large-scale land-use changes, and exploitation of natural resources from terrestrial and marine ecosystems (Steffen et al. 2011; Corlett 2015). Altogether this results in significant changes in the rates and directions of many abiotic and biotic processes and in ecosystem changes that alter vital conditions for life and concomitantly cause species extinctions (Hautier et al. 2015). Cumulative and synergistic effects, reinforcing processes and positive feedbacks further complicate these changes, whose overall effects are hard to predict (Wassen et al. 2013).

Climate change is one of the global changes attracting much attention worldwide for a number of reasons, but according to Rockström et al. (2009) biodiversity loss and interference in the nitrogen cycle are-with climate change-already beyond a safe operating space, and global freshwater use and global land-use changes are approaching their planetary boundaries. Global change research on one hand focuses on analysing global trends in carbon, temperature, cycling of water and nutrients and biodiversity (Vörösmarty et al. 2010; Liu et al. 2015) and on the

T. Okruszko

Faculty of Building Services, Hydro and Environmental Engineering, Warsaw University of Technology, Pl.

Politechniki 1, 00-661 Warsaw, Poland other hand on attempting to model global processes and their interactions via Global Circulation Models or Earth System Models (e.g. Delworth et al. 2006; Baumgaertner et al. 2013). However, equally important is the analysis of environmental change at regional or local scales in order to better understand the local effects of global change (Witte et al. 2012) or, alternatively, to ascertain how local measures can restore ecosystem functioning and thus improve understanding of how local changes relate to larger regional or continental scales (De Boer et al. 2011; Grand-Clement et al. 2013; Miettinen et al. 2013).

In Europe, as in other continents, freshwater wetlands have been reclaimed and drained for agriculture, or have disappeared after being cut off from rivers that have been trained for safety purposes (Okruszko et al. 2011; Davidson 2014; Verhoeven 2014). However, it is difficult to disentangle the causes of change in wetlands, since interferences occur simultaneously but their starting times might differ and are sometimes even unknown, initial conditions were not recorded and the intensity of interference might have changed. For these reasons, in most areas it is almost impossible to construct realistic cause-effect relationships of wetland change.

In this paper we attempt to analyse changes in a lowland river valley that harbours important marsh and fen ecosystems i.e. the Biebrza wetland in Poland $\left(53^{\circ} 28^{\prime} \mathrm{N}, 22^{\circ} 39^{\prime} \mathrm{E}\right)$. The wetlands are still in a relatively natural state, the history of land use and water management is well known and the wetlands have been studied extensively. We used a range of meteorological and hydrological long-term monitoring data such as air temperature, precipitation, snow depth, evapotranspiration and river discharge, which were compared with current and historical vegetation, soil-moisture and water management maps. Our study aims at separating the effects of local changes in management from global changes in climate factors that might have caused the observed changes in the hydrology of the wetlands and the distribution of ecosystems. We hypothesize that using a multiparameter approach, taking into account meteorological, hydrological, vegetation and soil conditions enables us to analyse long-term changes that result from a complex combination of different impact factors. 


\section{Materials and methods}

Study area

The Biebrza wetlands lie in the Biebrza River valley in north-eastern Poland (Fig. 1) in the Podlaska Lowland. They comprise undrained floodplains, marshes and fens surrounded by a post-glacial landscape with ice-pushed hills, moraines and outwash plains. The near-natural character of the wetlands is reflected in a regular pattern of plant communities which run the length and breadth of the river valley. Although a number of its tributaries have been trained and turned into drainage canals, the river is unregulated, meandering throughout the length of the valley and with many oxbow lakes. In spring, extensive areas are flooded by the river, snowmelt, rain and groundwater (Chormański et al. 2011; Keizer et al. 2014).

The riparian vegetation consists of reed-beds and the floodplain contains highly productive rich fen (Wassen et al. 2006). These are relatively species-poor tall sedge, grass and herb vegetations. Further from the river are abundant low-productivity sedge fen types containing many Red List species. In an intermediate belt, beyond the seasonal river flood zone and where the calcareous groundwater from the moraines does not reach the fen surface, poor fen and transitional fen types are present, fed mainly by rainwater. The importance of conserving the immense ecological value of the Biebrza wetlands has been recognized internationally and nationally. The Biebrza River valley is designated as a wetland site of global significance in the Ramsar Convention, it belongs to the Natura 2000 EU Ecological Network (PLH200008) and has the status of national park (Biebrza Nationa Park), covering an area of 59,800 ha.

Hydrological and climatic data

The hydrological and meteorological data were obtained from the Institute of Meteorology and Water Management (IMGW). The dataset covered the period

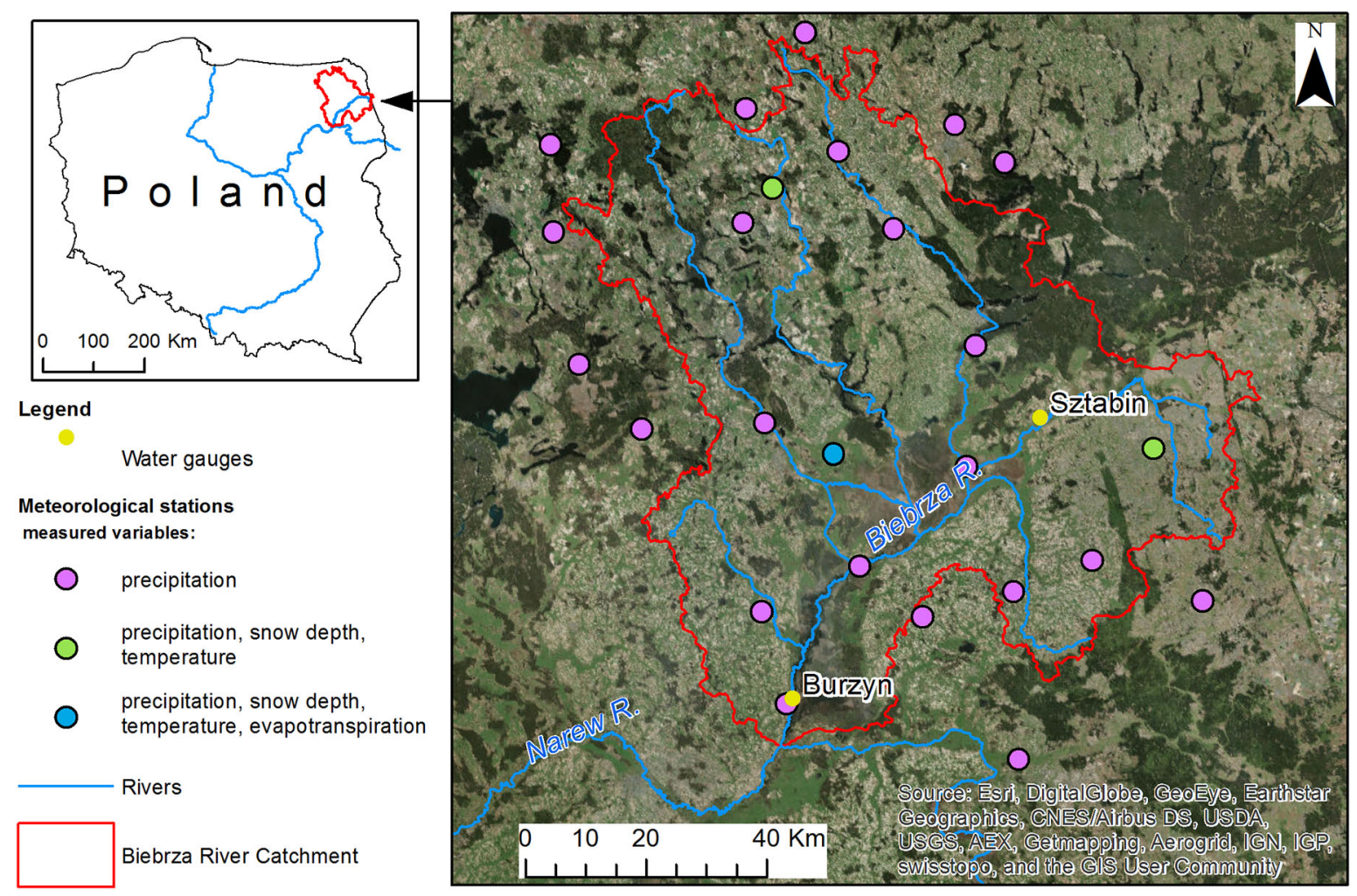

Fig. 1 Location of the study area in Poland, delineation of the Biebrza catchment and locations of water gauges and meteorological stations. Meteorological stations differ in the number of variables measured 
1962-2012 for daily records of precipitation, minimum and maximum air temperature, snow depth, and for the period 1951-2012 for river discharge. The reference evapotranspiration was calculated with the Penman-Monteith equation (Allen et al. 1998), with data registered in one station for the period 1960-2009 for a daily resolution for the growing season i.e. 1 April to 30 September. The values of reference evapotranspiration reflect evapotranspiration from a reference surface with no water stress, thus are related to atmospheric conditions and do not reflect the actual evapotranspiration in the study area, which depends on soil moisture and vegetation conditions too. Figure 1 shows the locations of meteorological stations and water gauges.

The discharge time series were obtained from two water gauges: Burzyn and Sztabin. The Burzyn gauge is located near the catchment outlet (the confluence of the Biebrza and Narew) thus the discharge here is driven by factors characteristic for the whole catchment $\left(7000 \mathrm{~km}^{2}\right)$, whereas the Sztabin gauge drains the upstream part of the Biebrza catchment $\left(700 \mathrm{~km}^{2}\right)$, which is the most extensively managed region of the study area. The catchments of the two water gauges contain similar proportions of peat soil: 16\% (Burzyn) and $17 \%$ (Sztabin).

Soil-moisture complexes maps

Soil-moisture complexes group soils with similar airwater conditions in the vadose zone of the soil profile (Okruszko 1998). They are named after the water regime (Okruszko and Ilnicki 2003): wet (A), periodically wet $(A B)$, moist $(B)$, periodically moist/periodically drying out (BC), drying out (C), periodically dry (CD) and dry (D). Soil-moisture complexes are generally used for selecting optimal management practices on grasslands and are thus good indicators of water conditions in soil.

In this study two maps of soil-moisture complexes were analysed (Fig. 2): a historical map, based on a survey in 1970 (Liwski et al. 1984) and a more recent map based on a survey in 1999 (Szunieiwcz et al. 2004). Both maps were registered in the same geographical coordinate system, and digitized, yielding a new map with polygons showing the intersection of the source maps. The attributes of this map allowed the magnitude and direction of the changes to be investigated. The maps overlapped for 54,035 ha: approximately $75 \%$ of the Biebrza River valley area.

Vegetation maps

To discover vegetation changes in the Biebrza valley, two vegetation maps were compared (Fig. 3): a map published by Palczynski (1984) based on data collected in the 1970s and early 1980s and a vegetation map made by Matuszkiewicz et al. (2000) based on a survey in 1997-1999. Changes were detected similarly to the analysis of soil-moisture complex maps. Since we were interested in the river valley only, we excluded from the analysis dry sandy dunes, high moraines and a large forested bog (Czerwono Bagno) on the northern edge of the valley in the middle basin. The maps overlapped for 45,040 ha, i.e. approximately $62 \%$ of the Biebrza River valley area. For the generalization of vegetation types of both maps into common vocabulary, see Online Appendices S1, S2.

Land use and water management

We compiled a database of historical information from published and unpublished sources, oral stories from locals and archive data of land ownership, agricultural practices and management measures (Wassen and Okruszko 1994; Wassen and Mioduszewski 1999). From this information we derived spatially explicit information about changes in land use and water management practices in the Biebrza catchment between 1960 and 2000. Agricultural practices in the catchment surrounding the valley were increasing in intensity and fertilizer gifts after Poland joined the EU in 2004 (GUS 2015). Since this was after the period for which we could compare soil moisture and vegetation data (up to 2000) we focused only on water and land use changes in the valley up to the year 2000. We constructed a map depicting water management measures, land management by farmers and nature management in the national park (Fig. 4).

\section{Statistical modelling}

The temporal changes in our dataset were analysed using statistical tests. First, linear monotonic trends in the time series were highlighted with the MannKendall test (Mann 1945; Kendall 1975). The sign of the $S$ statistics obtained from this test indicates 


\section{6}

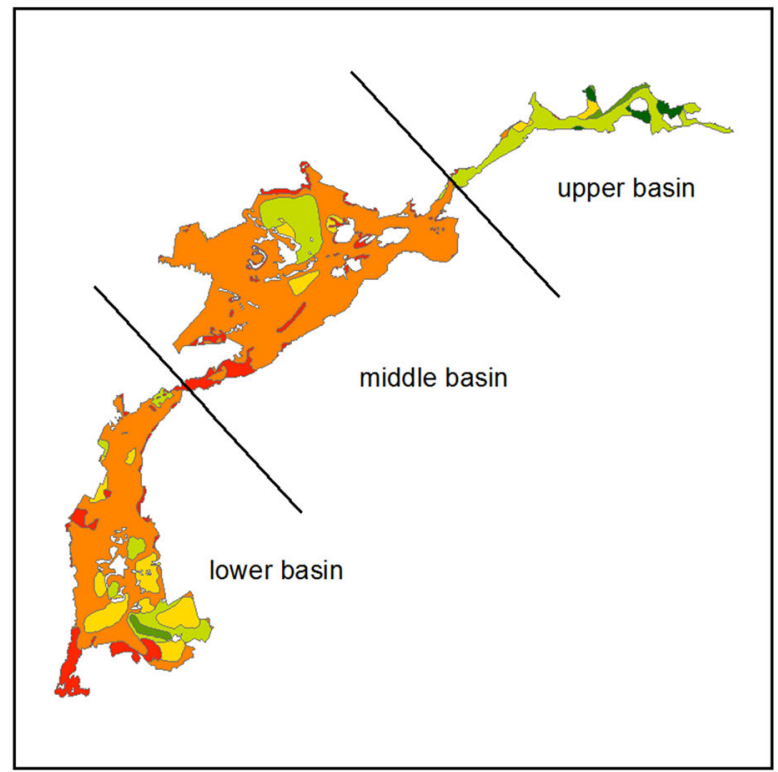

2000

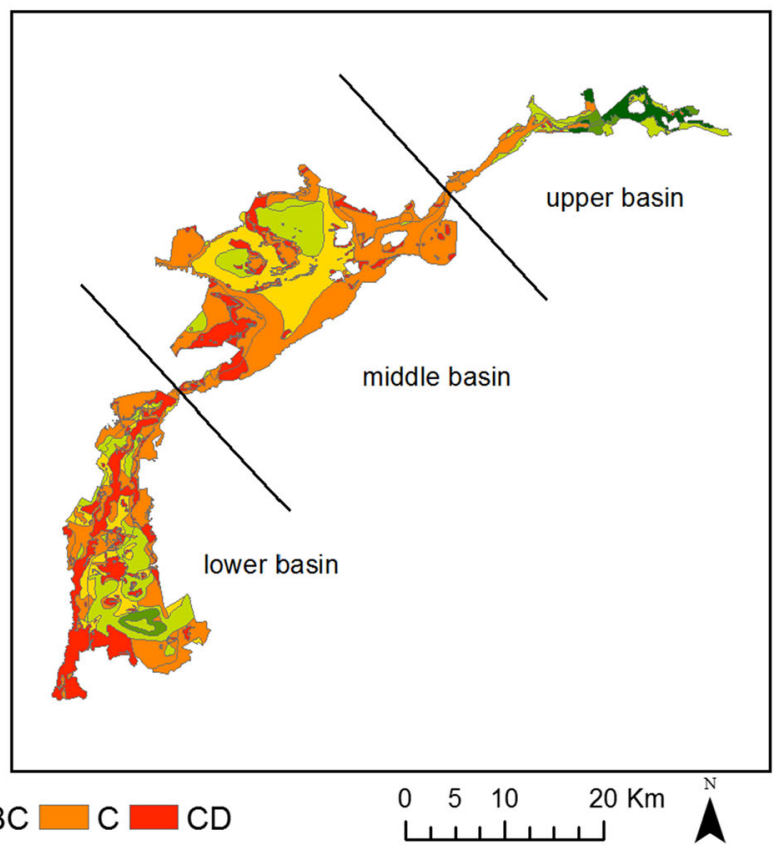

Fig. 2 Distribution of soil-moisture complexes in 1976 and 2000 in the Biebrza valley, A-wet, AB-periodically wet, B-moist, $\mathrm{BC}-$ periodically moist/periodically drying out, drying out $-\mathrm{C}, \mathrm{CD}$ - periodically dry

whether the trend is positive or negative. Next, we calculated the slope $(a)$ of the linear regression line which was fit to the time series. The slope gives information analogous to the $S$ statistics but is more straightforward and frequently used. For both $S$ and $a$ we calculated the $p$ values to analyse if the statistics are significant. When mentioning in the Results section that a statistic result was significant it means that the $p$ value $<0.05$.

\section{Results}

Hydrological and climatic data

Major changes during the last 50 years are clearly visible in air temperature, reference evapotranspiration and river discharge characteristics; precipitation and snow depth remain stable.

The minimum temperatures show significant increasing trends for January, April, July and August (Fig. S1). The trend in maximum temperatures is similar, but also with a significant positive trend in March (Fig. S2). The greatest rises in temperature are in January and April $\left(0.081{ }^{\circ} \mathrm{C}\right.$ year $\left.{ }^{-1}\right)$ for the maximum temperatures and in January $\left(0.096{ }^{\circ} \mathrm{C}\right.$ year $^{-1}$ ) for the minimum temperatures.

The only months showing significant trends in precipitation are January and February (increasing trend) and November (decreasing trend) (Fig. S3). The biggest increase in monthly precipitation is in January $\left(0.339 \mathrm{~mm}\right.$ year $\left.^{-1}\right)$; the biggest decrease in monthly precipitation is in November $\left(-0.379 \mathrm{~mm} \mathrm{year}^{-1}\right)$.

Monthly reference evapotranspiration figures show significant increasing trends in April, May and August (Fig. S4). During the middle and end of the growing season (June, July and September) no significant trends occur. The reference evapotranspiration increases to $0.339 \mathrm{~mm} \mathrm{year}^{-1}$ for May.

The monthly mean snow depth does not show any significant trend (Fig. S5). However, the time series shows a general tendency of decreasing snow depths at the end of the winter (February and March).

The mean yearly river discharge for the Burzyn gauge increases significantly by $0.202 \mathrm{~m}^{3} \mathrm{~s}^{-1}$ year $^{-1}$, mostly in the winter half-year (Fig. S6). By contrast, the Sztabin gauge has a stable mean discharge for all seasons, with insignificant trends (Fig. S6). The minimum annual discharge at both locations increases during the winter half-year and for the Burzyn cross- 

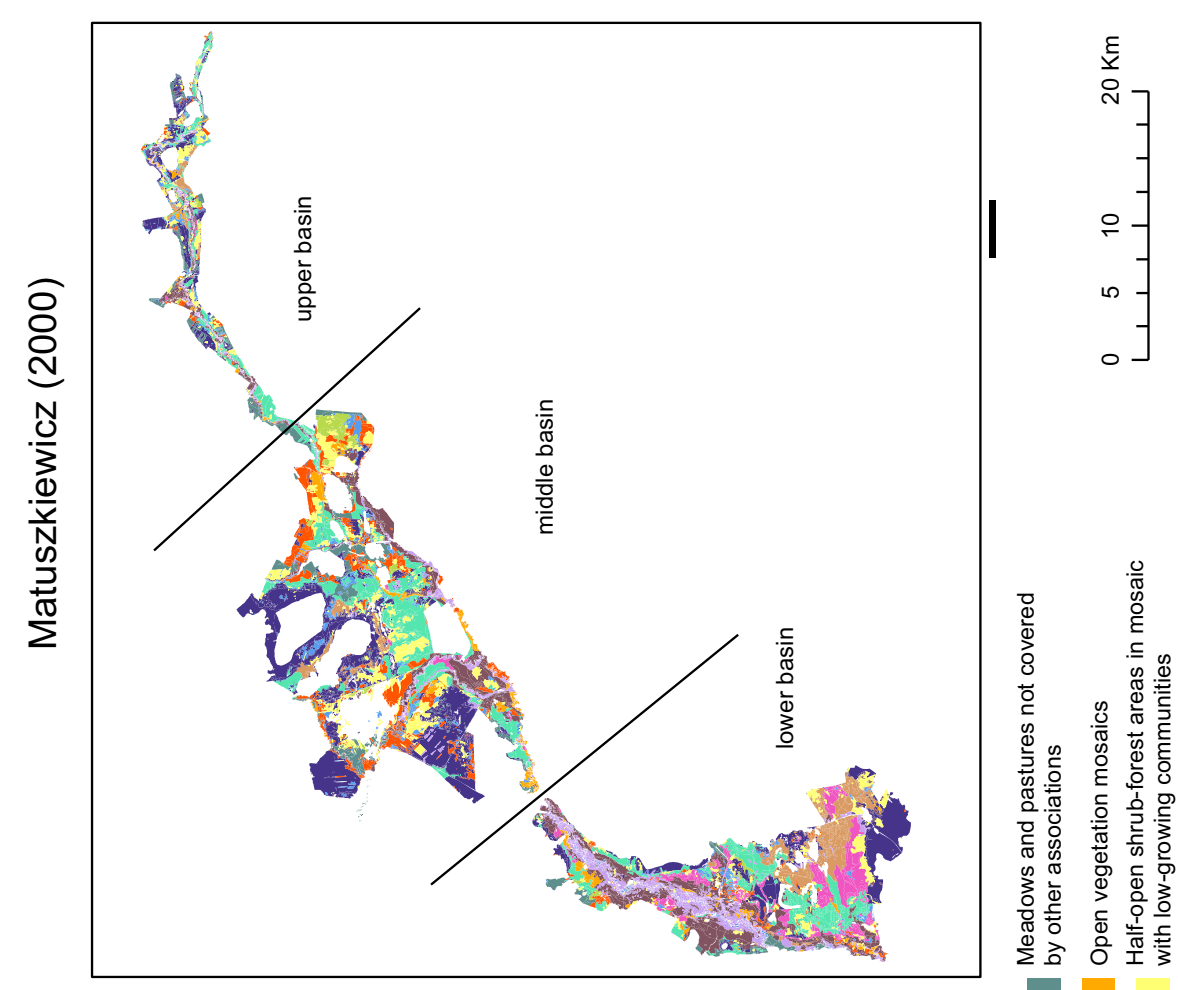

สิ
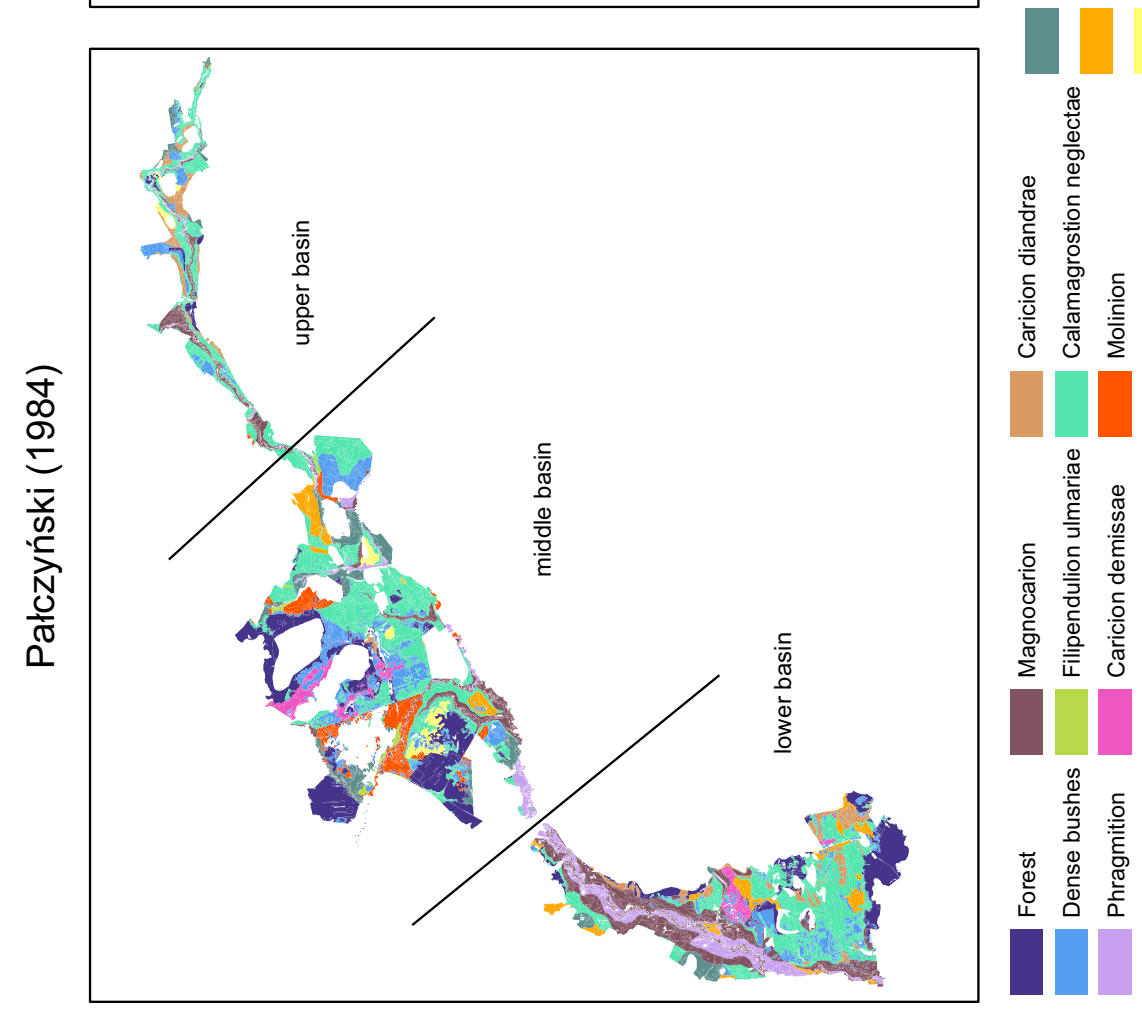

II 


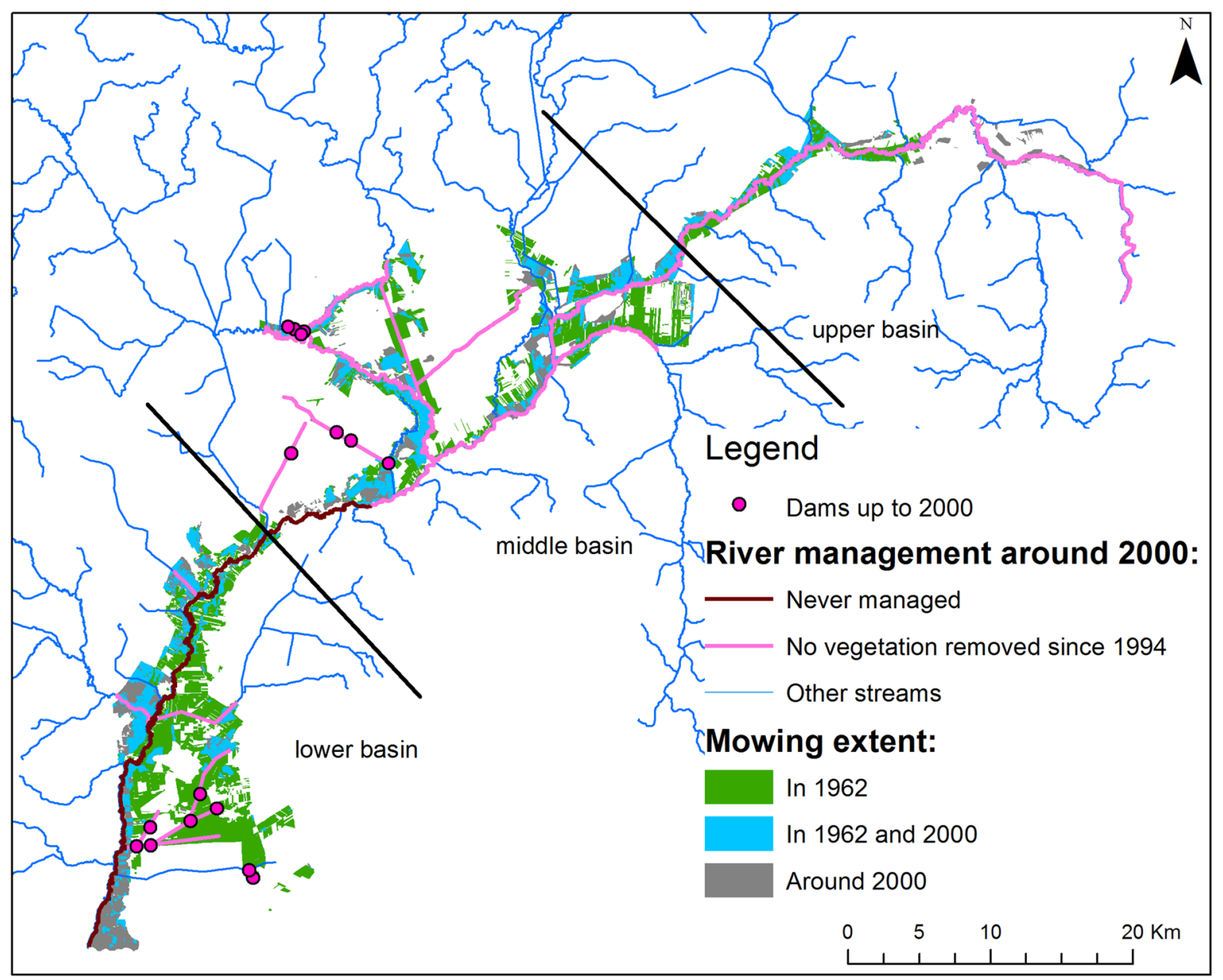

Fig. 4 Land-use changes and management practices in the Biebrza River valley

section for the whole year too. Maximum discharges decrease, but the trends are significant only for Sztabin for the yearly period and the winter half-year. The summer half-year characteristics for both cross-sections do not show significant maximum discharge trend statistics.

\section{Soil-moisture complexes}

Between 1970 and 2000 although most (25,345 ha) soil-moisture complexes remained stable, in 17,221 ha the soil-moisture complexes shifted towards higher moisture, and in 11,471 ha the soil moisture decreased (Table 1). The biggest change towards moister complexes was from drying out (C) to periodically moist/periodically drying out (BC): it occurred in 7201 ha (13.3\% of overlap). The biggest change towards drier conditions was from drying out (C) to periodically dry (CD) and comprised 6997 ha (12.9\%). Nevertheless, the most stable complex was $\mathrm{C}$ : its area remained unchanged at 17,145 ha $(31.7 \%$ of the overlap of the maps). Zooming in on the spatial patterns of soil moisture changes (Fig. 5) it becomes clear that especially the area close to the source of the Biebrza River, became wetter between 1976 and 2000, as also generally occurred in the middle basin, where large areas of drying areas changed into wetter types. In the lower basin the picture is more diverse. In 1976 most of the area contained drying soils. In 2000 the belt along the river changed from drying out $(C)$ into even drier types classified as CD and D. Further from the river the scattered picture of 2000 shows that intermediate dry soils became wetter whereas elsewhere a shift towards dryer types occurred (cfr. 
Table 1 Changes in soil-moisture complexes between 1970 and 2000

\begin{tabular}{|c|c|c|c|}
\hline From $>$ To & Area (ha) & Trend & Relative change $(\%)$ \\
\hline$C>C$ & 17,145 & . & 31.7 \\
\hline $\mathrm{C}>\mathrm{BC}$ & 7201 & + & 13.3 \\
\hline $\mathrm{C}>\mathrm{CD}$ & 6997 & - & 12.9 \\
\hline $\mathrm{B}>\mathrm{B}$ & 4207 & . & 7.8 \\
\hline$C>B$ & 3358 & + & 6.2 \\
\hline $\mathrm{CD}>\mathrm{CD}$ & 2269 & . & 4.2 \\
\hline $\mathrm{BC}>\mathrm{B}$ & 2180 & + & 4.0 \\
\hline $\mathrm{CD}>\mathrm{C}$ & 2087 & + & 3.9 \\
\hline $\mathrm{B}>\mathrm{C}$ & 1995 & - & 3.7 \\
\hline $\mathrm{BC}>\mathrm{C}$ & 1049 & - & 1.9 \\
\hline $\mathrm{BC}>\mathrm{BC}$ & 1041 & . & 1.9 \\
\hline $\mathrm{B}>\mathrm{A}$ & 751 & + & 1.4 \\
\hline $\mathrm{B}>\mathrm{AB}$ & 625 & + & 1.2 \\
\hline $\mathrm{A}>\mathrm{A}$ & 476 & . & 0.9 \\
\hline $\mathrm{CD}>\mathrm{BC}$ & 396 & + & 0.7 \\
\hline $\mathrm{B}>\mathrm{BC}$ & 377 & - & 0.7 \\
\hline $\mathrm{BC}>\mathrm{CD}$ & 332 & - & 0.6 \\
\hline $\mathrm{B}>\mathrm{CD}$ & 326 & - & 0.6 \\
\hline $\mathrm{AB} \longrightarrow \mathrm{A}$ & 231 & + & 0.4 \\
\hline $\mathrm{BC}>\mathrm{AB}$ & 225 & + & 0.4 \\
\hline $\mathrm{AB}>\mathrm{B}$ & 220 & - & 0.4 \\
\hline $\mathrm{AB}>\mathrm{AB}$ & 207 & . & 0.4 \\
\hline $\mathrm{A}>\mathrm{B}$ & 123 & - & 0.2 \\
\hline $\mathrm{C}>\mathrm{AB}$ & 84 & + & 0.2 \\
\hline $\mathrm{CD}>\mathrm{B}$ & 69 & + & 0.1 \\
\hline $\mathrm{A}>\mathrm{C}$ & 21 & - & 0.0 \\
\hline $\mathrm{AB} \longrightarrow \mathrm{C}$ & 19 & - & 0.0 \\
\hline $\mathrm{BC}>\mathrm{A}$ & 14 & + & 0.0 \\
\hline $\mathrm{A}>\mathrm{CD}$ & 6 & - & 0.0 \\
\hline $\mathrm{AB}>\mathrm{CD}$ & 5 & - & 0.0 \\
\hline $\mathrm{A}>\mathrm{AB}$ & 0 & - & 0.0 \\
\hline
\end{tabular}

A-wet, $\mathrm{AB}$ - periodically wet, $\mathrm{B}$-moist, $\mathrm{BC}$-periodically moist/periodically drying out, drying out $-\mathrm{C}, \mathrm{CD}-$ periodically dry. Trend symbols: "+" wetter, "-" drier, “." stable. Relative change shows percentage of changed area in relation to the area of all soil-moisture complexes

Figs. 2, 5). Taking into account that the soil complexes $\mathrm{A}$ and $\mathrm{AB}$ are the only ones which led to the peat forming process, the scale of changes show more halting the decay of peatlands then restitution of mires.
Vegetation

Inspection of the vegetation maps acquired for the two snapshots in time reveals that for most communities the regular pattern of larger uninterrupted areas of a certain community in 1984 seems to have disintegrated into one of much more scattered smaller patches by 2000 (Fig. S2). Also striking are the stability of the large forest areas in the middle and lower basins, the widespread conversion of the Calamagrostietum neglectae throughout the valley into several other vegetation types and the expansion of reed and tall sedge marshes (Phragmition and Magnocaricion) in the lower basin. The area of Calamagrostion neglectae (low-growing grass vegetation with low sedges and forbs) shrank by over half (7376 ha lost: Table 2). The forested area increased by 3060 ha, a 44\% increase since 1984 (Table 2). The total area under dense bushes declined by 3442 ha, but in the upper part of the Biebrza basin it increased (Fig. 3). The total wooded area (forest + dense bushes) was almost stable, decreasing slightly to 97\% of the 1984 area. The class "half-open shrubforest areas in mosaic with low-growing communities" gained the most, increasing more than sixfold (Table 2). This change is visible in all three basins, but especially in the upper basin, where it replaced Calamagrostion neglectae and Caricion diandrae (Fig. 3). Another class composed of mosaics, the "open vegetation mosaics" lost 435 ha-almost a quarter of its previous area (Table 2).

The reed-bed area (Phragmition) increased by approximately 346 ha, to $114 \%$ of its size in 1984 (Table 2). In that year the alliance was hardly present in the upper part of the Biebrza basin, but it now forms a continuous belt throughout the valley. This belt was already present in the middle and lower basins, but in the approximately 20-year interval between the maps it widened (Fig. 3).

The area under Molinietalia meadows of the Molinion and Filipendulion alliances increased markedly in the analysed area (Table 2). Molinion increased by 1640 ha $(+90 \%)$ and Filipendulion by 425 ha $(+177 \%)$. The "meadows and pastures not covered by other associations" mostly include land under intensive agriculture; their total area has remained stable (Table 2).

The total area under tall sedge communities (Magnocaricion alliance) shows an overall loss of 225 ha, 
Fig. 5 Changes in soilmoisture complexes. Dams and river management are also indicated

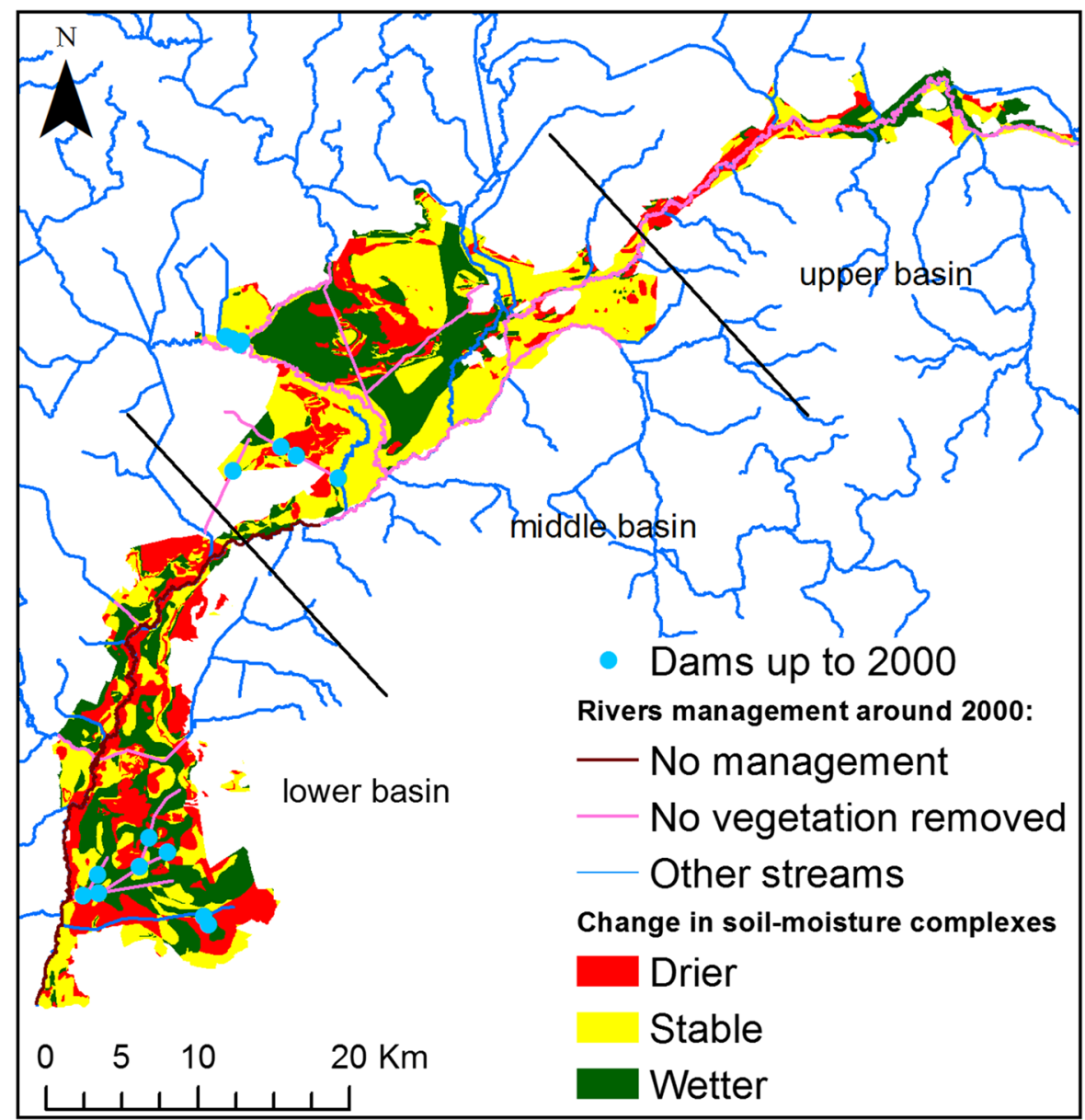

but it increased in the middle basin (Fig. 3). However, the area under Caricion diandrae (the low-growing sedge-moss communities) has almost doubled since 1984, gaining 1147 ha. Most of this gain was achieved at the expense of Calamagrostion neglectae in the lower basin.

The class of Caricion demissae has increased its cover by $169 \%$ of the 1984 area (Table 2). This gain occurred in the lower basin, where Calamagrostion neglectae was replaced; in the middle basin the class lost ground to Caricion diandrae.

Vegetation changes in Biebrza valley show various magnitude and direction (Table S1). Roughly 60-70\% of the area of most communities was lost to other communities. The community with the highest relative change is Calamagrostion neglectae, which lost $71 \%$ of its 1984 area to other communities. The most stable community is forest, which is currently also the most abundant in the study area. Its area changed by only $13 \%$, but an important share of this (5\%) was a change into half-open shrub-forest, which is an arbitrary change that might be attributable to differences in the mapping methodology.

A large part of the area of Calamagrostion neglectae changed into diverse other communities, most of which consist of half-open shrub-forest, Caricion demissae, Caricion diandrae, Molinion, Magnocaricion and forest; each of these changes covers about $3 \%$ of the study area (Table S1).

\section{Discussion}

Hydrological and meteorological variables

The minimum and maximum air temperatures show a positive trend in the spring and summer months, which directly determines an increasing reference 
Table 2 Areas covered by different "Alliances" in the Biebrza valley on the Pałczyński and Matuszkiewicz maps, respectively

\begin{tabular}{|c|c|c|c|c|c|c|}
\hline Alliance & $\begin{array}{l}\text { P. area } \\
\text { (ha) }\end{array}$ & $\begin{array}{l}\text { Relative cover } \\
\text { fraction P map }\end{array}$ & $\begin{array}{l}\text { M. area } \\
\text { (ha) }\end{array}$ & $\begin{array}{l}\text { Relative cover } \\
\text { fraction } \mathrm{M} \text { map }\end{array}$ & $\begin{array}{l}\text { Size of } \\
\text { change (ha) }\end{array}$ & $\begin{array}{l}\text { Relative } \\
\text { change }\end{array}$ \\
\hline Forest & 6994 & 0.16 & 10,054 & 0.22 & 3060 & 1.44 \\
\hline Dense bushes & 5198 & 0.12 & 1756 & 0.04 & -3442 & 0.34 \\
\hline Phragmition & 2493 & 0.06 & 2839 & 0.06 & 346 & 1.14 \\
\hline Magnocarion & 5812 & 0.13 & 5587 & 0.12 & -225 & 0.96 \\
\hline Filipendulion ulmariae & 240 & 0.01 & 666 & 0.01 & 425 & 2.77 \\
\hline Caricion demissae & 1187 & 0.03 & 2361 & 0.05 & 1175 & 1.99 \\
\hline Caricion diandrae & 1669 & 0.04 & 2816 & 0.06 & 1147 & 1.69 \\
\hline Calamagrostion neglectae & 14,665 & 0.33 & 7289 & 0.16 & -7376 & 0.50 \\
\hline Molinion & 1828 & 0.04 & 3468 & 0.08 & 1640 & 1.90 \\
\hline $\begin{array}{l}\text { Meadows and pastures not covered by other } \\
\text { associations }\end{array}$ & 2444 & 0.05 & 2427 & 0.05 & -16 & 0.99 \\
\hline Open vegetation mosaics & 1803 & 0.04 & 1369 & 0.03 & -435 & 0.76 \\
\hline $\begin{array}{l}\text { Half-open shrub-forest areas in mosaic with } \\
\text { low-growing communities }\end{array}$ & 708 & 0.02 & 4409 & 0.10 & 3701 & 6.23 \\
\hline Total & 45,040 & 1.00 & 45,040 & 1.00 & 0 & - \\
\hline
\end{tabular}

$P$ Pałczyński, $M$ Matuszkiewicz. "P area" and "M area" shows the alliances' area on both maps. "Relative cover fraction" of an alliance is the area of the alliance as a proportion of the area of all alliances on that map. "Size of change" is the area of an alliance in the Pałczyński map subtracted from the corresponding area in the Matuszkiewicz map. "Relative change" for each alliance is the Matuszkiewicz area divided by the Pałczyński area

evapotranspiration. These trends could be expected to influence river discharge in summer, but do not, since on average the river discharge increases from year to year both for Burzyn and Sztabin (Fig. S6). The peak discharges (during the spring flood) are decreasing, which is related to decreasing snow depths (Fig. S5) from November to March. The importance of snow for hydrological processes in the Biebrza catchment has been shown by hydrological modelling (Berezowski et al. 2015). As their study shows, discharge in Burzyn is sensitive to changes in the spatial distribution of snow cover.

The centre of mass of the yearly hydrograph, which indicates the period of the highest discharge (i.e. the spring flood), occurs earlier and earlier each year (Fig. S7). This shift is also probably related to the decreasing snow depths throughout the winter resulting in snow melting progressively earlier at the end of the winter.

Similar findings were presented by Ignar et al. (2011), who developed a hydrodynamic model of river flow for calculating annual floods in the Lower Biebrza River Basin. Their results show that the maximum flood area, flood volume and mean water depth decreased during 1965-2000, but not statistically significantly.

\section{Soil-moisture complexes}

An increase in soil moisture occurred predominantly in areas where conservation measures have been implemented (Fig. 5). The first such measure, implemented since 1994, is the prohibition of the removal of aquatic plants from the river. This measure is clearly related to river flow velocity and other hydraulic parameters (Verschoren et al. 2017). Its biggest impact is in the upper basin, where the valley is narrow and dominated by peat soils. The aquatic vegetation reduces the flow velocity and thus raises the water level in the river and the soil moisture content in the surrounding ecosystems. This area (and central part of the Middle Basin) remain the only ones where peat forming process still take place. An important measure was abandonment of drainage ditches in some parts of the river valley. These ditches have silted up and become vegetated, curtailing water discharge. Next measure was the construction of dams in most drainage canals in the lower and middle basins, which 
delayed the runoff from the valley to the river), thereby preventing the valley from drying out in water-deficit periods. Increase of the soil moisture protects bigger area from peat decay but still does not bring Biebrza Wetlands to their original status. This is a part of the broader problem of future of the wetlands in the boreal region. The described herein management measures were successfully applied also in other wetlands for increasing water table; however, they do not always lead to full restoration of wetlands features such as carbon sequestration, vegetation composition and peat properties (Wilcox et al. 2006; Schimelpfenig et al. 2014).

\section{Vegetation}

The comparison of the two maps revealed two types of vegetation change (Fig. 3), both leading to a loss of the open sedge-moss communities.

The first is vegetation change resulting from succession in a similar pattern as reported for other wetlands (Rosenthal 2010). Such changes are expressed in the valley in two ways: (1) invasion by reed-beds and tall sedges (Phragmition alliance) and (2) increase of forested area. Both are believed to result from dereliction of management in the valley (Palczynski 1984). However, the decrease in the area under dense bushes is not what one would expect as the effect of abandonment of management practices. It could, be a result of generalizing the two maps; the area under dense bushes in the Pałczyński map will have been overestimated if the Pałczyński associations that were thought to be bushy were not dense enough to qualify as. And this would be more in line with findings from other research in the area (Palczynski 1984; Schmidt et al. 2000).

In the second type of vegetation changes, management practices seem to have been continued or even intensified. Here the grass/sedge-moss communities of the Calamagrostietum neglectae and Caricion diandrae have been replaced by meadows of the Molinietalia order (mostly in the middle basin) or intensively used meadows (upper basin).

Looking at the role of management in the Biebrza valley, distinctions can be made among the three basins.

In the upper basin, peat analysis has revealed that open vegetation started to develop under the influence of permanent groundwater seepage (Wassen et al.
2002). Later, it seems that although hydrological conditions were favourable for shrubs, trees and reeds, regular mowing kept the fen vegetation open and low. Evidence supporting this hypothesis is the increase of forest, shrubs and Phragmition in the unmanaged areas of the upper basin.

The same can be said for the parts of the middle basin, where forest or Phragmition plant communities replaced the sedge-moss communities. But in other large parts of the middle basin the sedge-moss communities were replaced by Molinietalia meadows. The peat muck soil of these litter meadows is susceptible for shrub and tree encroachment (Palczynski 1984). So the fact that these areas changed from sedge-moss to Molinietalia vegetation and were kept open suggests that they were still being mown regularly.

The lower basin is different. Here the vegetation changes are smallest, though dereliction of management was also signalled here. It was the only basin in which the area under plant communities of the Calamagrostietum neglectae and Caricion diandrae remained stable. The lower basin of the Biebrza floods almost entirely every year, because of a fluvial cone at its southern end, which elongates the hydroperiod by acting as a dam. The hydroperiod and other flood parameters are known to drive the wetland vegetation composition (Murray-Hudson et al. 2015) which might explain the failure of shrubs and trees to colonize large parts of the lower basin. Plant communities of the Phragmition alliance can cope better with these floods than shrubs and trees. Moreover, Phragmition have expanded its cover as a consequence of the dereliction of management and extension of the dry belt around the river (Fig. 2).

As reported also in other studies, management can be a very important factor in preserving open fen vegetation (Güsewell 2003; Middleton et al. 2006; Sundberg 2012). That can be seen in the upper basin, where a relatively undamaged hydrological system alone could not preserve open vegetation without management (Wassen and Joosten 1996). However, management alone cannot preserve vegetation, as evidenced from the middle basin, where Molinietalia meadows replaced the Calamagrostietum neglectae and Caricion diandrae fen vegetation, though shrubs and trees did not encroach. In the lower basin, however, management was subservient to hydrology 
as, despite reduction in management, vegetation changes were small.

So management can be crucial to preserve open fen vegetation, although it need not be essential. Without proper hydrological conditions vegetation will change despite any management, although it seems that under sub-optimal hydrological conditions management enables vegetation to persist.

\section{Management measures}

For Biebrza we identified a number of management measures that may mitigate the effect of climate change. Firstly, building-up dams in the main river tributaries increases the adjacent soil moisture and promotes suitable conditions for certain vegetation types. Next, ceasing vegetation removal in large stretches of the river diminishes river discharge rates similarly to building river dams. Vegetation removal from the river bed was a practice aimed at increasing the water velocity and decreasing water levels in the river and adjacent areas for agriculture. Hence, desertion of vegetation removal maintains natural water levels and increases adjacent soil moisture. Effectively these two management measures have an important role in mitigating water shortages that may result from climate change; either too low precipitation, seasonal variation in snow pack patterns and enhanced evaporation.

A third measure is mowing which ceases succession and promotes early successional stages and hence prevents succession to later successional stages such as shrubs, bushes and forests. Important in relation to climate change is the effect on transpiration. Low growing sedges and grasses transpire less water than shrubs and trees (Grygoruk et al. 2014). Hence, mowing in the Biebrza valley effectively conserves water and increases water retention. It is important to realize that cattle grazing and harvesting hay for feed of livestock was a traditional farming practice in Biebrza for centuries and was nearly abandoned in the mid 20th century (Budka et al. 2013).

\section{Synthesis and conclusions}

Contrary to expectations, higher summer temperatures and evapotranspiration combined with no significant change in precipitation has not led to drier soils.
Instead, our results show that the area of wet soil moisture complexes increased over 25 years. There is a clear spatial correlation between wetter soils and the locations where ditches have been closed off or filled in: (1) disconnecting ditches in the lower basin from the main drainage system increased moisture in and around these ditches; and (2) stopping the clearing of aquatic plants from the river in the upper basin increased soil moisture. This indicates that local water management measures had more effect on soil wetness than the observed climatic changes for the summer period. Further evidence for the impact of human intervention is the decrease in soil wetness in the area still managed quite intensively by farmers in the lowest part of the upper basin.

Peak river discharges have decreased and spring floods are occurring earlier each year. This is probably due to a temperature increase and shorter duration of the snow period, although meteorological data do not fully support this. The effect of discharge changes may be twofold: earlier snowmelt and flooding causes generally drier conditions in the summer since evapotranspiration and drainage by the river gradually diminishes the water availability (Kaznowska 2007; Van Loon and Van Lanen 2012). In addition, the decreasing peak discharges cause drying in the soil near the river and thus the dry belt around the river in the lower basin is widening. The observed vegetation change from Magnocaricion to Phragmition in the lower basin shows that this drying is also consistently reflected in the vegetation, since replacement of tall sedge marshes by reedland is generally observed in drained areas (Barendregt et al. 1995) and was simulated as a possible climate change effect on hydrology and ecology in a UK wet grassland (Thompson et al. 2009). Other vegetation changes reflect local rewetting measures (van Diggelen et al. 2006) or abandonment of regular mowing practices that leads to shrub and tree encroachment (Kotowski et al. 2006). Hence, our findings confirm the conclusion from another case study (Ethiopia) that water management techniques appear to be effective in keeping wetland degradation in check (Dixon 2002).

Our results support the general finding that besides land management, water is one of the most important factors determining the status of fluviogenous ecosystems (Junk et al. 1989). Hydraulic modelling of the Biebrza valley shows that there are strong relationships between inundation frequency and the 
occurrence of different wetland ecosystems (Okruszko et al. 2010) and that a significant congruity exists between the type of vegetation and calculated flood characteristics (Swiatek et al. 2008). These studies as well as our analysis show that the vast wetland communities of the Lower Biebrza River Valley are characterized by frequent and very long ( 6 months per year) inundation. Swiatek et al. (2008) also showed that biotic and abiotic conditions are strongly linked: the abiotic conditions affect biota, and vice versa. Via its roughness, vegetation cover influences the wetness of the floodplain and thus appreciably controls the flooding process. The expansion of tall-growing vegetation such as reeds affects flood characteristics such as area flooded, flood depth and flooding frequency (Swiatek et al. 2008). Hence the expansion of reedlands that we observed as a response to the drying of the belt of soil close to the river may in the future be reversed by the reeds retarding floodwater.

This paper shows that a multi-parameter approach taking into account meteorological, hydrological, vegetation and soil conditions is elucidating in identifying impact factors and their different effects. We demonstrated this for the Biebrza wetlands; a large European wetland of international importance, using long-term monitoring data of more than 40 years.

The management measures have been shown to be capable of diminishing the expected effects of climate change. This conclusion is important in the ongoing discussion about the efficacy of conservation and restoration measures aiming at maintaining optimal wetland ecosystem functions under future anthropogenic changes. The strength of the multi-parameter approach we used is that the detection and explanation of changes can be reviewed much more holistically than in conventional monodisciplinary studies. We studied the period 1960-2000. Since the Biebrza wetlands are internationally significant and protected under Polish and EU legislation, data collection has been continued and extended and in the coming 2-3 years we may expect new vegetation and soil surveys of the whole area allowing for improved comprehensive analyses.

Acknowledgements We acknowledge IMGW-PIB for providing hydrological and meteorological data for this paper. We also acknowledge Biebrza National Park (especially Helena Bartoszuk) answering multitude of our request concerning spatial data.
Open Access This article is distributed under the terms of the Creative Commons Attribution 4.0 International License (http:// creativecommons.org/licenses/by/4.0/), which permits unrestricted use, distribution, and reproduction in any medium, provided you give appropriate credit to the original author(s) and the source, provide a link to the Creative Commons license, and indicate if changes were made.

\section{References}

Allen RG, Pereira LS, Raes D, Smith M (1998) Crop evapotranspiration-guidelines for computing crop water requirements. FAO Irrigation and drainage paper 56. FAO, Rome

Barendregt A, Wassen MJ, Schot PP (1995) Hydrological systems beyond a nature reserve, the major problem in wetland conservation of Naardermeer (Netherlands). Biol Conserv 72:393-405

Baumgaertner AJG, Thayer JP, Neely RR III, Lucas G (2013) Toward a comprehensive global electric circuit model: atmospheric conductivity and its variability in CESM1(WACCM) model simulations. J Geophys Res Atmos 118:9221-9232

Berezowski T, Nossent J, Chormanski J, Batelaan O (2015) Spatial sensitivity analysis of snow cover data in a distributed rainfall-runoff model. Hydrol Earth Syst Sci 19:1887-1904

Budka M, Marczakiewicz P, Lachmann L, Krogulec J (2013) Management plan for the Biebrza National Park. Biebrzański Park Narodowy, Osowiec (in Polish)

Chormański J, Okruszko T, Ignar S, Batelaan O, Rebel K, Wassen M (2011) Flood mapping with remote sensing and hydrochemistry: a new method to distinguish the origin of flood water during floods. Ecol Eng 37:1334-1349

Corlett RT (2015) The Anthropocene concept in ecology and conservation. Trends Ecol Evol 30:36-41

Crutzen PJ, Stoermer EF (2000) The 'Anthropocene'. Glob Change Newsl 41:17-18

Davidson NC (2014) How much wetland has the world lost? Long-term and recent trends in global wetland area. Mar Freshw Res 65:934-941

De Boer HJ, Lammertsma EI, Wagner-Cremer F, Dilcher DL, Wassen MJ, Dekker SC (2011) Climate forcing due to optimization of maximal leaf conductance in subtropical vegetation under rising $\mathrm{CO}_{2}$. Proc Natl Acad Sci 108:4041-4046

Delworth T, Broccoli Anthony J, Rosati Anthony, Stouffer Ronald J, Balaji V, Beesley John A, Cooke William F, Dixon Keith W, Dunne John et al (2006) GFDL's CM2 global coupled climate models-Part 1: formulation and simulation characteristics. J Clim 19:643-674

Dixon AB (2002) The hydrological impacts and sustainability of wetland drainage cultivation in Illubabor, Ethiopia. Land Degrad Dev 13:17-31

Grand-Clement E, Anderson K, Smith D, Luscombe D, Gatis N, Ross M, Brazier RE (2013) Evaluating ecosystem goods and services after restoration of marginal upland peatlands in South-West England. J Appl Ecol 50:324-334 
Grygoruk M, Batelaan O, Mirosław-Świątek D, Szatyłowicz J, Okruszko T (2014) Evapotranspiration of bush encroachments on a temperate mire meadow-a nonlinear function of landscape composition and groundwater flow. Ecol Eng 73:598-609

GUS (2015) Local Data Bank database form the Central Statistical Office. www.stat.gov.pl. Accessed 2015

Güsewell S (2003) Management of Phragmites australis in Swiss fen meadows by mowing in early summer. Wetl Ecol Manag 11(6):433-445

Hautier Y, Tilman D, Isbell F, Seabloom EW, Borer ET, Reich PB (2015) Anthropogenic environmental changes affect ecosystem stability via biodiversity. Science 348:336-340

Ignar S, Maksymiuk-Dziuban A, Miroslaw-Siatek D, Chormański J, Okruszko T, Wysocki P (2011) Temporal variability of the selected flood parameters in the Biebrza River valley. Ann Wars Univ Life Sci-SGGW Land Reclam 2:135-142

Junk WJ, Bayley PB, Sparks RE (1989) The flood pulse concept in river-floodplain systems. In: Dodge DP (ed) Proceedings of the International Large River Symposium. J. Can. Fish. Aquatic Sci. 11, pp. 106-127

Kaznowska E (2007) Analysis of hydrological drought in the Biebrza River at the Burzyn gauge 1951-2002. In: Okruszko T, Maltby E, Szatyłowicz J, Świątek D, Kotowski W (eds) Wetlands: monitoring, modelling and management. CRC Press, Boca Raton, pp 3-8

Keizer F, Schot P, Okruszko T, Chormanski J, Kardel I, Wassen M (2014) A new look at the flood pulse concept: the (ir)relevance of the moving littoral in temperate zone rivers. Ecol Eng 64:85-99

Kendall MG (1975) Rank correlation methods, 4th edn. Charles Griffin, London

Kotowski W, Thörig W, van Diggelen R, Wassen MJ (2006) Competition as a factor structuring species zonation in riparian fens-a transplantation experiment. Appl Vegetation Sci 9:231-240

Liu J, Mooney H, Hull V, Davis SJ, Gaskell J, Hertel T, Lubchenco J, Seto KC, Gleick P, Kremen C, Li S (2015) Systems integration for global sustainability. Science 347:1258832

Liwski S, Maciak F, Okruszko H, Churski T, Gotkiewicz J, Oświt J, Pacowski R, Szuniewicz J, Żurek S (1984) Characteristics of soil formation and soils and their evolution due to draining and different utilization. Pol Ecol Stud 10:313-346

Mann HB (1945) Non-parametric tests against trend. Econometrica 13:163-171

Matuszkiewicz AJ, Głowacka I, Jakubowski W, Kamiński J, Myśliński G, Sobczyński L (2000) Plan Ochrony Biebrzańskiego Parku Narodowego. Operat: Ochrona lądowych ekosystemów nieleśnych. NFOŚiGW, BPN, Warszawa

Middleton BA, Holsten B, Diggelen R (2006) Biodiversity management of fens and fen meadows by grazing, cutting and burning. Appl Vegetation Sci 9:307-316

Miettinen J, Wang J, Hooijer A, Liew S (2013) Peatland conversion and degradation processes in Insular Southeast Asia: a case study in Jambi, Indonesia. Land Degrad Dev 24:334-341

Murray-Hudson M, Wolski P, Cassidy L, Brown MT, Thito K, Kashe K, Mosimanyana E (2015) Remote Sensing-derived hydroperiod as a predictor of floodplain vegetation composition. Wetl Ecol Manag 23(4):603-616

Okruszko H (1998) System of fen-peat soils description used in Poland. J Water Land Dev 2:63-73

Okruszko H, Ilnicki P (2003) The moorsh horizons as quality indicators of reclaimed organic soils. In: Parent LE, Ilnicki $\mathrm{P}$ (eds) Organic soils and peat materials for sustainable agriculture. CRC Press, Boca Raton, pp 12-25

Okruszko T, Chormański J, Mirosław-Świątek D, Gregorczyk M (2010) Hydrological characteristics of swamp communities, the Biebrza River (NE Poland) case study. In: Christodoulou J, Stamou P (eds) Environmental Hydraulics. Taylor \& Francis Group, London, pp 407-412

Okruszko T, Duel H, Acreman M, Grygoruk M, Flörke M, Schneider C (2011) Broad-scale ecosystem services of European wetlands - overview of the current situation and future perspectives under different climate and water management scenarios. Hydrol Sci J 56:1-17

Palczynski A (1984) Natural differentiation of plant communities in relation to hydrological conditions of the Biebrza valley. Pol Ecol Stud 10:347-385

Rockström J, Steffen W, Noone K et al (2009) Planetary boundaries: exploring the safe operating space for humanity. Ecol Soc 14(2):32

Rosenthal G (2010) Secondary succession in a fallow central European wet grassland. Flora-Morphol Distrib Funct Ecol Plants 205(3):153-160

Schimelpfenig DW, Cooper DJ, Chimner RA (2014) Effectiveness of ditch blockage for restoring hydrologic and soil processes in mountain peatlands. Restor Ecol 22:257-265

Schmidt A, Piórkowski H, Bartoszuk H (2000) Remote sensing techniques and geographic information systems for wetland conservation and management: monitoring scrub encroachment in Biebrza National Park. Wageningen, Rapport Alterra

Steffen W, Persson $\AA$, Deutsch L et al (2011) The Anthropocene: from global change to planetary stewardship. Ambio 40:739-761

Sundberg S (2012) Quick target vegetation recovery after restorative shrub removal and mowing in a calcareous fen. Restor Ecol 20:331-338

Świątek D, Szporak S, Chormański J, Okruszko T (2008) Hydrodynamic model of the Lower Biebrza River flow-A tool for assessing the hydrologic vulnerability of a floodplain to management practices. Ecohydrol Hydrobiol 8:331-337

Szunieiwcz J, Chrzanowski S, Bieniek B (2004) Gleby hydrogeniczne w Dolinie Biebrzy. In: Banaszuk H (ed) Kotlina Biebrzańska i Biebrzański Park Narodowy. Wydawnictwo Ekonomia i Środowisko, Białystok

Thompson JR, Gavin H, Refsgaard A, Sørenson HR, Gowing DJ (2009) Modelling the hydrological impacts of climate change on UK lowland wet grassland. Wetl Ecol Manag 17(5):503-523

van Diggelen R, Middleton B, Bakker J, Grootjans A, Wassen M (2006) Fens and floodplains of the temperate zone: present status, threats, conservation and restoration. Appl Vegetation Sci 9:157-162

Van Loon AF, Van Lanen HAJ (2012) A process-based typology of hydrological drought. Hydrol Earth Syst Sci 16:1915-1946 
Verhoeven JTA (2014) Wetlands in Europe: perspectives for restoration of a lost paradise. Ecol Eng 66:6-9

Verschoren V, Schoelynck J, Cox T, Schoutens K, Temmerman S, Meire P (2017) Opposing effects of aquatic vegetation on hydraulic functioning and transport of dissolved and organic particulate matter in a lowland river: a field experiment. Ecol Eng 105:221-230

Vörösmarty CJ, McIntyre PB, Gessner MO, Dudgeon D, Prusevich A, Green P, Davies PM (2010) Global threats to human water security and river biodiversity. Nature 467:555-561

Wassen MJ, Joosten JHJ (1996) In search of a hydrological explanation for vegetation changes along a fen gradient in the Biebrza Upper Basin (Poland). Vegetatio 124:191-209

Wassen MJ Mioduszewski W (1999) Assessment of the effect of changes in water management within the Central Biebrza Basin. Final Report PIN-MATRA project Ministry of Agricultue, Nature Management and Fisheries and Ministry of Foreign Affairs, Falenty/Utrecht

Wassen MJ, Okruszko H (1994) Towards protection and sustainable use of the Biebrza Wetlands: Exchange and integration of research results for the benefit of a Polish-Dutch
Joint Research Plan. In: Selected papers for the European Union Workshop 'Biebrza Wetlands', IMUZ, Falenty

Wassen MJ, Bleuten W, Bootsma MC (2002) Linking hydrology to ecology; Biebrza as a geographical reference. Ann Wars Agric Univ 33:27-47

Wassen MJ, Okruszko T, Kardel I, Chormański J et al (2006) Eco-hydrological functioning of Biebrza Wetlands: lessons for the conservation and restoration of deteriorated wetlands. Ecol Stud 191:285-310

Wassen MJ, de Boer HJ, Fleischer K, Rebel KT, Dekker SC (2013) Vegetation-mediated feedback in water, carbon, nitrogen and phosphorus cycles. Landsc Ecol 28:599-614

Wilcox D, Sweat M, Carlson M, Kowalski K (2006) A waterbudget approach to restoring a sedge fen affected by diking and ditching. J Hydrol 320(3-4):501-517

Witte J, Runhaar J, Ek R, Van Der Hoek DC et al (2012) An ecohydrological sketch map of climate change impacts on water and natural ecosystems for the Netherlands: bridging the gap between science and society. Hydrol Earth Syst Sci 16:3945-3957 